\title{
Specimen at Room Temperature
}

National Cancer Institute

\section{Source}

National Cancer Institute. Specimen at Room Temperature. NCI Thesaurus. Code C70719.

A specimen that has been subjected to and adjusted to the average ambient temperature of a room, usually considered to be around 20 degrees C (68 degrees F). 